
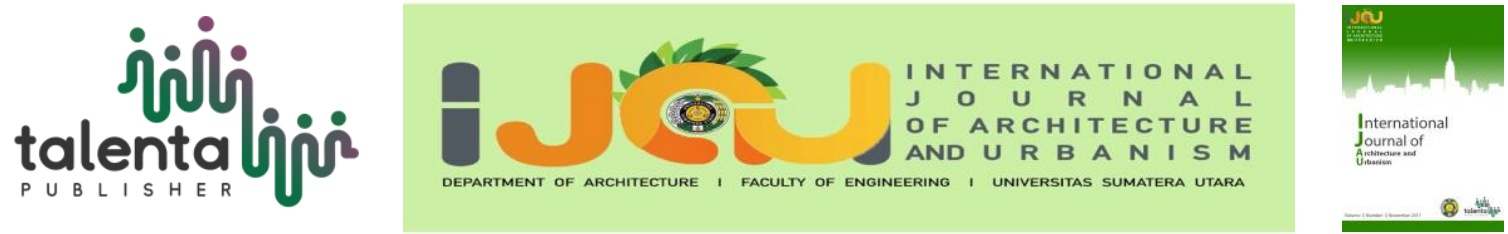

\title{
Museum and Gallery of Contemporary Art Medan (Contemporary Architecture)
}

\author{
Imam Faisal Pane ${ }^{1 *}$, Rahmita Dewi Lubis ${ }^{1}$ \\ ${ }^{1}$ Department of Architecture, Universitas Sumatera Utara, Medan, Indonesia
}

\begin{abstract}
The Museum is a place to see showpieces as art, artifacts, and other cultural relics. The purpose of the museum is not only for education but also as entertainment. This design takes the case study of a contemporary art museum. This museum has a gallery, which function is to sell and auction the contemporary art. This Museum and Gallery designed with contemporary architecture style, suitable for the main function of the building which is museum and gallery of contemporary art. The museum and gallery will also help to develop the tourism in Medan and to be an education facility to the public. There are few steps made in the process of completing the design; the first one is by collecting data from the literature, books, journal, magazine, the internet, survey, and interview. And from the data collected, the design for Museum and Gallery of Contemporary Art will be produced.
\end{abstract}

Keyword: museum, gallery, contemporary, art

\section{Introduction}

As time goes by art will always improve. Art gives benefits to the world by economic aspect, the social aspect, and culture aspect. As the modern time comes so does art, and we can see the differences. Contemporary art is an art that develops today. Some contemporary artworks are painting, sculpture, installation, video, photography, and performance. The development of art is not only for education purpose but also improve the economics of the city, which as recreation facility that can bring visitors both locally and internationally. The introduction of contemporary art can be through an art museum, where the visitors can learn while recreating. Medan has history museum, nationality museum, and wildlife museum, but this city hasn't got the museum of art, where this also the obstacles for the artist and art lovers, they don't have a facility to show their artwork. The design of museum and gallery of contemporary art in Medan expected to support the activities of art and also become the new recreation place in Medan.

*Corresponding author at:Department of Architecture, Faculty of Engineering, Universitas Sumatera Utara, Jalan Perpustakaan Gedung J07, Medan 20155, Indonesia

E-mail address: imamfpane@gmail.com 


\section{Literature Review}

The location takes place at Abdul Hakim Street, Kampung Susuk, Medan Selayang, Medan (Figure 2). The existing site is a rice field which has measurement about 8.15 acre. In 2030 base on Medan Space System Detail Plan (Figure 1) this site will become a commercial site which becomes the advantage to build art museum where lots of visitors will come to here. The site location is boundary by an urban house, and across it, there is an apartment but still under construction. This 8.15 -acre site will be designed as a commercial district, consisting of hotel, mall, youth center, and museum.

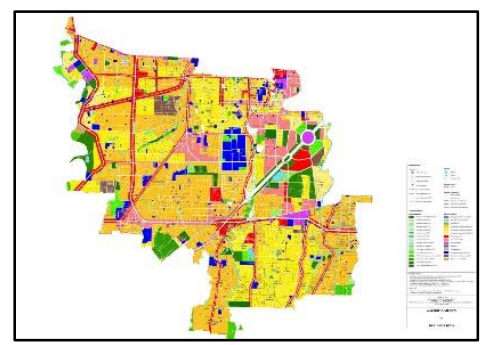

Figure 1. Space System Detail Plan (Source: Medan Government)

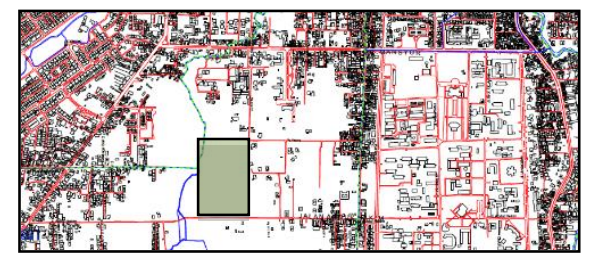

Figure 2. Site Location

The Museum of Contemporary Art is showing contemporary art, such as paintings, installation, video, photography, and performance. How to display this artwork is free-standing, and on the wall or by panels. The organization of the artworks must have a story line, so when the visitors see it, and they will understand. There are few standard architectural criteria which must be followed to design a museum; they are lighting, air flow, circulation, and few supported rooms for the activity [4]. According to Laurence V. Coleman from her book "Museum Building," there are several things about room needs and how big it should be to support the activities inside the building. The rooms are exhibition hall in permanent and temporary room, administration room, curatorial room, preparation room, registration room, library, education room, and service room. How big the museum should also be determined by how much the population in that city, more population bigger the building will be. The artwork must have a well-prepared room so the visitors can see the art clearly (Table 1). Human point of view is $54^{\circ}$ and $27^{\circ}$ with $32.8 \mathrm{ft}$ and with the lighting that has an illumination level provision. Each object has different illumination level, start from the 5-foot-candle for the costume, textile, animal skin, and vegetation, 20-foot candle for oil paintings, and 30-foot candle for metal, and stone [1]. 
Table 1.Artwork Standard Spacious

\begin{tabular}{|l|l|}
\hline Room needed by & Spacious needed \\
\hline Paintings & $3-5 \mathrm{~m}^{2}$ wide wall \\
\hline Sculpture & $6-10 \mathrm{~m}^{2}$ wide floor \\
\hline Small pieces & $1 \mathrm{~m}^{2}$ cabinets \\
\hline
\end{tabular}

(Source. Neufert, 1997, page 135)

Museum of Contemporary Art in Chicago also one of the contemporary art museum. It has more than 5000 artworks inside. Their artworks are paintings, installation, video, etc. (Figure 3). This museum takes place in Chicago, Illinois, USA. The museum using gallery concept as their representation to visitors. They have permanent and temporary exhibition area. The museum built to honor the most influenced artist from that town, Ludwig Mies van der Rohe, and Louis Sullivan. The museum not only has a gallery room for the showcase, but it also has a multifunction theatre with 296 seats. The theatre can be used for performance or any other occasion. The museum also has the most amazing staircase, which aesthetic, the curve and the shape are amazing (Figure 4). The lighting using natural and artificial lighting.

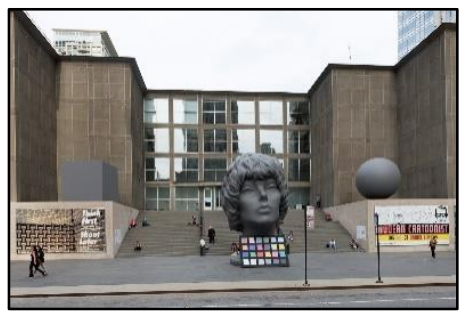

Figure 3. Installation Artwork (Source: 10best.com/destination/Illionois/Chicago)

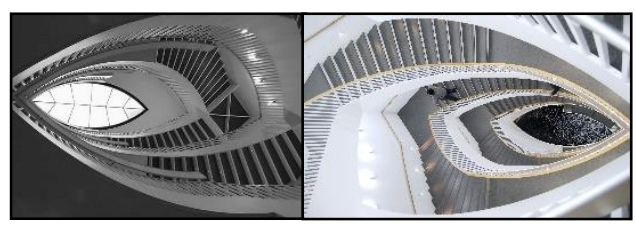

Figure 4. The staircase from down and up elevation (Source: thinkvisual.wordpress.com)

The style that used for the design of Museum and Gallery of Contemporary Art is contemporary architecture. The election of that style is because this is the contemporary art museum, so the museum also using that style, beside that contemporary style suitable for this era. Contemporary architecture is an architecture which expressed form to deliver a message to the visitors, the characteristics of this style are building expression is subjective, contrast with the surrounding environment, showing a unique mass, extraordinary, and attractive. The principles of contemporary architecture are sturdy building, an open space concept, the harmonization between outside and inside, has a transparent façade, and intrinsic comfortable. Comparative study of similar style is Tate Modern in London. The Tate Modern is a modern art museum (Figure 5). This museum design by Herzog \& de Meuron. The museum used to be London's Bankside Power Station. The museum famous with the chimney tower and contrast with the skylight; they use it as the lighting of the room (Figure 6). The room which used to be power 
station now become the exhibition hall, and because of the skylight, it still looks like a power station [3]. The geometry of the building reflects what contemporary architecture is, the floor plan, the façade of the building using bricks, and a lot of apertures.

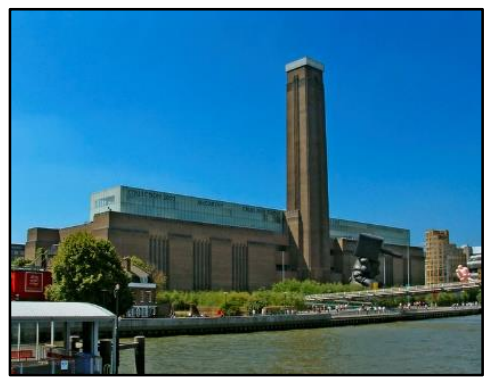

Figure 5. The Tate Modern London (Source: Archdaily)

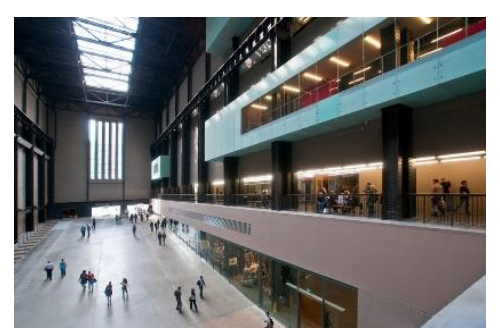

Figure 6. Tate Modern's Hall (Source: Archdaily)

\section{Methodology}

The research design's type is qualitative research. It is a subjective research which using analysis. The results are descriptive data in the form of words of people and observable behavior. By surveying the location we can collect any required data for the design of landscape, needed, and regulations. The method of this research divided into two data, primary and secondary data. Primary data is data that we got from the location. The results are site condition, site regulations, pictures of the site, and any information about site surrounding by interviewing with people around the neighborhood, artist, and common people. Secondary data is data that we got from literature study. We can collect it from books, journals, the internet, magazines, etc. From this methods, we can find any data that is required to design a Museum and Gallery from standardization, room needed, circulation, number of visitors, and any other information. From the site description, it is suitable for the museum to build, because it is going to be a commercial area, and close to the education facilities, from elementary school to university, and close to the settlement. Below are the data about site location (Table 2). This land has five potentials, which can profitable for the museum, it is between three highway, Jl. Setibudi, Jl. Jamin Ginting, and Jl. Ring road, close to the education facilities, the location is not too crowded, the land has quite a large area and easy accessibility. 
Table 2. Site Location Data

\begin{tabular}{|l|l|}
\hline Project Title: & $\begin{array}{l}\text { Museum and Gallery of } \\
\text { Contemporary Art Medan }\end{array}$ \\
\hline Project Status: & Fictitious \\
\hline Location: & $\begin{array}{l}\text { Abdul Hakim Street, Kampung } \\
\text { Susuk, Medan Selayang, Medan }\end{array}$ \\
\hline \multirow{2}{*}{ Site Boundary: } & North: Settlement \\
\cline { 2 - 2 } & South: Apartment and rice field \\
\cline { 2 - 2 } & West: Settlement and river \\
\cline { 2 - 2 } & East: Settlement \\
\hline Land Area: & 6.671 Acre \\
\hline Land contour: & Flat \\
\hline Existing building: & None \\
\hline
\end{tabular}

\section{Results and Discussion}

From the collected data now we can proceed to the next task which is designing the building. In this case, the building using contemporary architecture style. The concept of this museum is people will not only come to study when they visit the museum but also they can do recreation while studying. Also, the building will apply a lot of aperture in the concept, and the building will follow the characteristics of contemporary architecture. The circulation must not have a cross section so the visitors can walk easily and see all the artworks. The museum has four stories and one basement, each floor had exhibition room and separated based on what artwork is show off in there. Each floor has separated zone where there are common zone, private zone, and service zone. The private zone is an area for the workers and placed where visitors can't reach them. The room in each floor explained on the table (Table 3).

Table 3. Space Program

\begin{tabular}{|c|c|c|}
\hline No. & Space Program Floor & Name of The Room \\
\hline \multirow[t]{9}{*}{1.} & \multirow[t]{9}{*}{ First Floor } & Lobby \\
\hline & & $\begin{array}{l}\text { Exhibition hall: permanent and temporary } \\
\text { hall }\end{array}$ \\
\hline & & Curatorial Room \\
\hline & & Souvenir shop \\
\hline & & Coffee shop \\
\hline & & Workshop room \\
\hline & & Outdoor area \\
\hline & & Fire control room \\
\hline & & Panel room \\
\hline \multirow[t]{6}{*}{2.} & \multirow[t]{6}{*}{ Second-floor } & Exhibition hall (Permanent) \\
\hline & & Library \\
\hline & & Souvenir shop \\
\hline & & Toilet \\
\hline & & AHU \\
\hline & & Panel room \\
\hline \multirow[t]{8}{*}{3.} & \multirow[t]{8}{*}{ Third-floor } & Exhibition hall (Permanent) \\
\hline & & Audio visual room \\
\hline & & Islamic prayer room \\
\hline & & Souvenir shop \\
\hline & & Toilet \\
\hline & & Warehouse \\
\hline & & $\mathrm{AHU}$ \\
\hline & & Panel room \\
\hline
\end{tabular}




\begin{tabular}{|c|c|c|}
\hline No. & Space Program Floor & Name of The Room \\
\hline \multirow[t]{3}{*}{4.} & \multirow[t]{3}{*}{ Fourth-Floor } & Gallery \\
\hline & & Auction room \\
\hline & & $\begin{array}{l}\text { Office: manager room, meeting room, } \\
\text { exhibition division, education division, } \\
\text { security room }\end{array}$ \\
\hline No. & Space Program Floor & Name of The Room \\
\hline \multirow[t]{8}{*}{5.} & \multirow[t]{8}{*}{ Basement } & Administrators and workers park area \\
\hline & & Loading dock \\
\hline & & Workers locker \\
\hline & & Ground Water Tank (GWT) \\
\hline & & Sewage Treatment Plant (STP) \\
\hline & & Transformer room \\
\hline & & Generator room \\
\hline & & Chiller room \\
\hline
\end{tabular}

The design concept is a region area managed by a private developer. This region area has four buildings with different functions; they are hotel, mall, youth center, and museum and gallery (Figure 8). Each of this building is connected by the sky bridge and ground pedestrian (Figure 7), to give pedestrian an easy access to reach all building. All the four buildings are placed by their height, function, and operational time. Hotel and mall are placed adjacent closely because hotel guest has their needs and consumption. As for youth center and museum placed in front of the region because they have short operational time only until $6 \mathrm{pm}$ and according to their height only four stories. This region is designed with an open space at the top of the road. This open space can be access by the sky bridge. The open space area is open for public, to enjoy the scenery of the city. It has some facilities like sitting area, jogging track, and garden.

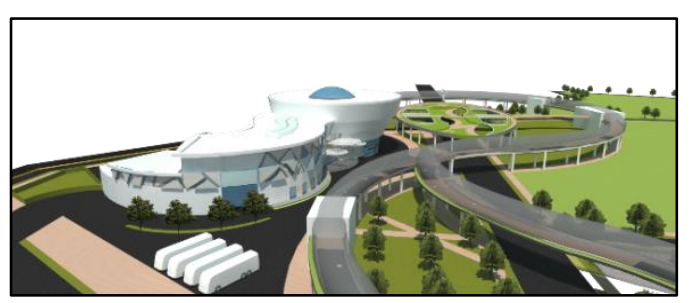

Figure 7. The sky bridge and open space design concept

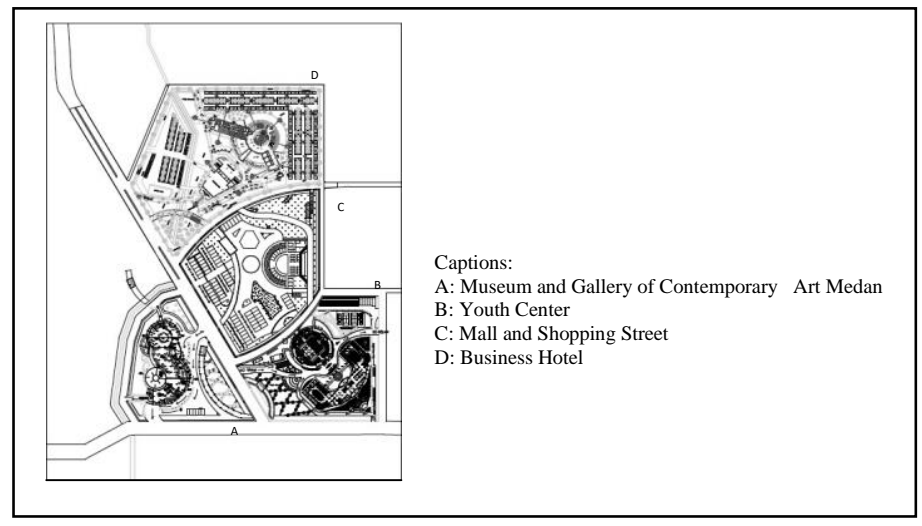

Figure 8. Masterplan Design

The circulation is an important thing when about to design a museum; it's the key to successful museum design. There are two circulations, landscape and inside building circulation. Both determine how the visitors will go through the museum from entering until finished. Landscape 
circulation is separated into three circulations, transport, pedestrian, and service circulation (Figure 9). The entrance of transport is from the main street, and they will be guided whether they want to drop off first or go the basement to park their car. All of the transport parking areas is in the basement except for buses. For the exit route is on Jl. Abdul Hakim and the street behind the museum near the river. The pedestrian can walk through the black lines, they are sky bridge and ground pedestrian, while the service circulation is separated so not interrupted the visitor's circulation, the entrance is on the street behind the museum near the river. Inside building circulation determined by the zone area inside (Figure 10). The zone area inside divided into two zones. First is common zone, where visitors can enter all zone here, they are the exhibition hall, souvenir shop, coffee shop, workshop room, toilet, etc. Second is private zone, is only workers and administrators allow to enter this zone, this zone is an area for, curatorial room, office, operational room, etc.

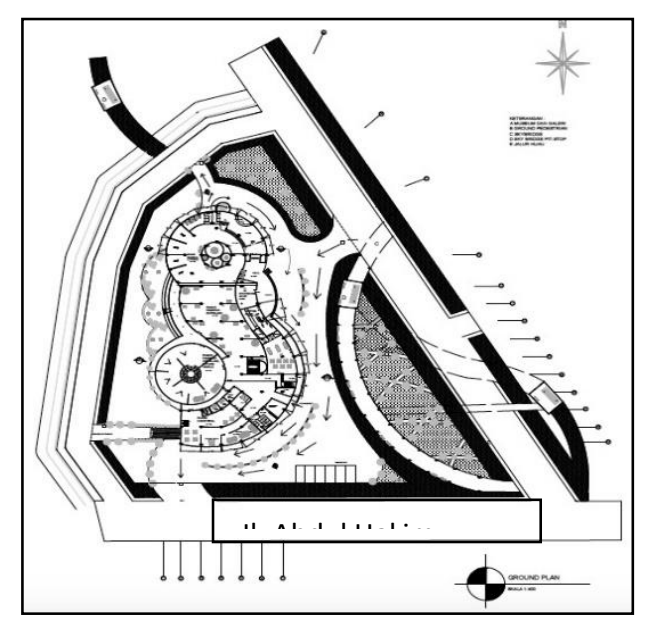

Figure 9. Circulation Path

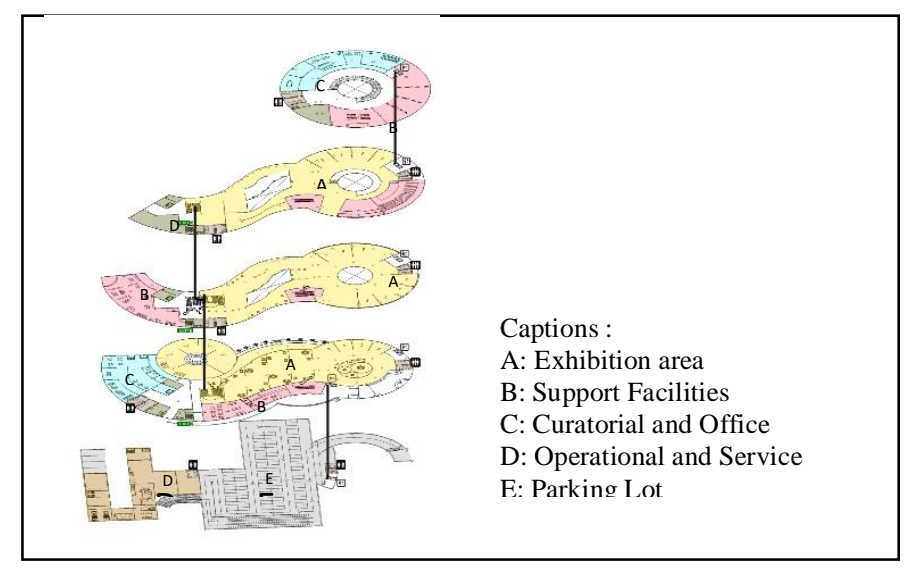

Figure 10. Floor Plan and Zoning Area

When visitors arrived, they can drop off first or go to the parking area. After that, they are buying the ticket at the ticket counter. At the first floor they will be introduced to the museum, what is contemporary art, then they can see paintings, sculpture, installation art, and future world. The second floor is an area for motion installation (Figure 11), an artwork where it's 
required a human motion to work the art and paintings (Figure 12). The third floor is an area for video installation and photography. The exit is at the souvenir shop; every floor has souvenir shop so when the visitors leave they can buy some souvenirs.

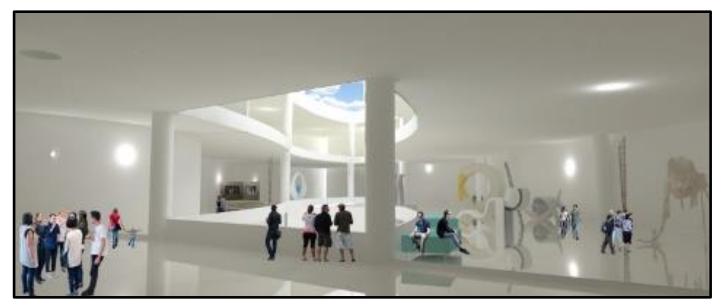

Figure 11. Motion Artwork Area

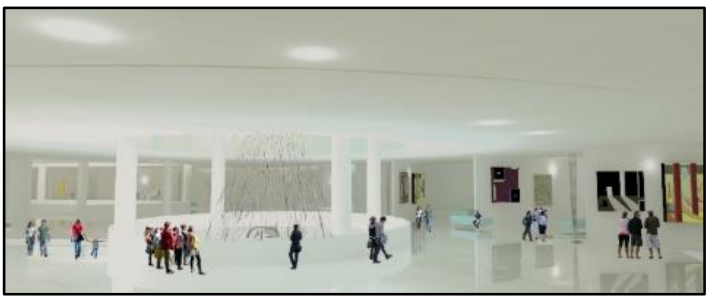

Figure 12. Paintings Area

The concept of mass inspired by the circulation form which is " $\mathrm{S}$ " and combined with a circle (Figure 13). It makes the mass more elastic and not stiff. On the circle form, the higher the floor, the larger the circle is. The mass also oriented to the open space across the museum.

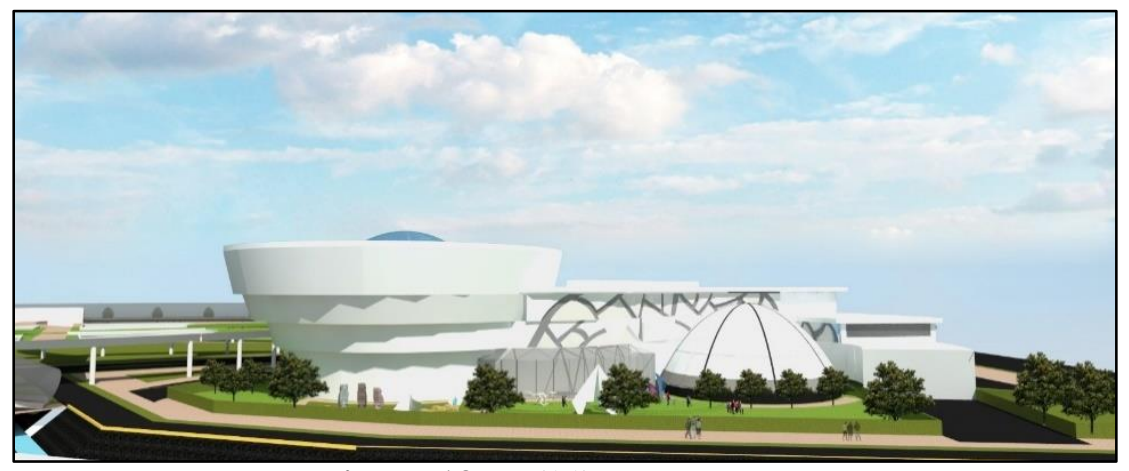

Figure 13. Building Mass Form

The façade is made of concrete and bricks, and some part covered by GFRC (Glass Fiber Reinforced Concrete). The wall is covered with textured white paint because white is a color which reflects calmness and modernity. For the ornament on the second and third floor, it was covered by GFRC, not just for aesthetic value but also as sun shading, where the sunlight can't enter directly into the building so can reduce the amount of it. As for the dome at the top building, it is made of space frame structure and acrylic glass and the "future world dome" is made of space frame structure and covered with GFRC.

\section{Conclusion}

Art is something that will always improve through the time. We need to appreciate and preserve it, the place where we can learn and see about art is at the museum. There we can understand 
what art is and not only learn, but we can do recreation in there. The museum exhibiting contemporary art; contemporary art is an art where it made at the present time, it represents the time it made. Kind of contemporary art is painting, sculpture, installation, video, photography, and performance. All of this kind of arts are available at Museum and Gallery of Contemporary Art Medan. Museum and Gallery of Contemporary Art Medan is a contemporary art museum located in Jl. Abdul Hakim. The design of this museum applying contemporary architecture style. It is applied to the mass form and façade. The mass composition is inspired by " $\mathrm{S}$ " word and circle form, together they are combined to make the mass composition. The paint chosen is white it represents modernity and the era now, where it also represents calmness. Some part of the façade is covered by GFRC to add some ornament to it.

The museum has four stories; each floor has exhibition area and operational room. Each floor separated into three zones, common, private, and service zone. The common zone is where visitors can enter every single room, while private and service zone, is an area where only workers and administrator can enter it. The service zone is located on the basement floor, but in each floor has panel room and AHU to control the electricity and air conditioning. The purpose of this design is to increase the creativity and knowledge of art while learning we can do fun things too, by visiting the museum we will appreciate more people's hard work and to preserve the art itself. And the museum will also increase the city's income, social, and culture. There are lots of benefits when you visit the museum.

\section{Acknowledgment}

This research is part of the requirement to obtain a bachelor's degree in Architecture Department, Universitas Sumatera Utara.

\section{REFERENCES}

[1] L. V. Coleman. Museum Buildings: A planning study (Vol. 1). American Association of Museums. 1950.

[2] E. Neufert. Data Arsitek, terjemahan: Sunarto Tjahjadi. Jakarta: Erlangga, 199. 1997.

[3] R. R. Moore; A. Hardwicke; and G. Stamp. Building Tate Modern: Herzog \& De Meuron Transforming Giles Gilbert Scott. London: Tate Gallery. 2000.

[4] P. Boylan and V. Woollard. Running a Museum: The Trainer's Manual: for Use with'Running a Museum: a Practical Handbook', UNESCO. 2006. 